\title{
PENGARUH PENDIDIKAN, PELATIHAN, DAN PENGALAMAN TERHADAP SKEPTISISME PROFESIONAL AUDITOR
}

\author{
Nurkholis \\ nurkholis@ub.ac.id \\ Jurusan Akuntansi, Fakultas Ekonomi dan Bisnis, Universitas Brawijaya
}

\begin{abstract}
Professional skepticism must be possessed by auditors in order to be able to detect indications of fraud and minimize audit risk. This study aims to examine the effect of education, training, and work experience on auditor professional skepticism. It is based on the theory of cognitive dissonance introduced by Festinger (1957). The data of this study were collected through a survey questionnaire distributed to auditors working at public accounting firms in Indonesia. The collected data were then processed statistically by using multiple linear regression analysis. The results show that auditors' education and work experiences have a positive effect on the auditor's professional skepticism. That is, the higher the level of education and the longer work experience, the level of professional skepticism the auditor has the better. While training variable does not affect the level of professional auditor skepticism. This research provides suggestion on the importance of professional staff development in accounting firms and, related to curriculum development in accounting schools, emphasizes the importance of introducing and adding insight into accounting students about the application of professional skepticism by public accounting profession/ external auditors.
\end{abstract}

Key words: education; training; work experience; auditor professional skepticism; puclic accounting firms.

\begin{abstract}
ABSTRAK
Skeptisisme profesional harus dimiliki oleh auditor untuk dapat mendeteksi indikasi kecurangan dan meminimalisasi risiko audit. Penelitian ini bertujuan untuk menguji pengaruh pendidikan, pelatihan, dan pengalaman kerja terhadap skeptisisme profesional auditor. Penelitian ini didasarkan pada teori disonansi kognitif yang diperkenalkan oleh Festinger (1957). Data penelitian ini dikumpulkan melalui kuesioner survei terhadap auditor yang bekerja pada Kantor Akuntan Publik di Indonesia. Data yang terkumpul kemudian diolah secara statistik dengan menggunakan metode analisis regresi linear berganda. Hasil pengujian menunjukkan bahwa variabel pendidikan dan variabel pengalaman kerja berpengaruh positif terhadap tingkat skeptisisme profesional auditor. Artinya, semakin tinggi tingkat pendidikan dan semakin lama pengalaman kerja, maka tingkat skeptisisme professional yang dimiliki auditor semakin baik. Sedangkan variabel pelatihan tidak berpengaruh terhadap tingkat skeptisisme professional auditor. Penelitian ini memberikan saran terhadap pentingnya pengembangan SDM di KAP dan, terkait pendidikan pengembangan kurikulum di lembaga pendidikan, juga menekankan pentingnya memperkenalkan dan menambah wawasan mahasiswa akuntansi tentang penerapan skeptisisme professional pada profesi akuntan publik atau auditor eksternal.
\end{abstract}

Kata kunci: pendidikan; pelatihan; pengalaman kerja; skeptisisme profesional auditor; kantor akuntan publik (KAP).

\section{PENDAHULUAN}

Peran auditor telah menjadi pusat kajian dan riset di kalangan akademisi. Tidak hanya itu, praktisi juga semakin kritis dengan selalu menganalisis kontribusi yang diberikan auditor. Auditor bertanggung jawab dalam pelaksanaan audit serta mendapatkan dan mengevaluasi bukti audit berdasarkan asersi manajemen untuk meyakinkan tingkat keterkaitan antara asersi tersebut dengan kriteria yang telah ditetapkan, serta mengkomunikasikan hasilnya 
kepada pengguna laporan keuangan. Tujuan akhir dari proses audit adalah untuk menghasilkan opini audit. Opini audit merupakan pernyataan atau pendapat auditor tentang kewajaran laporan keuangan, sehingga bisa dijadikan acuan bagi pengguna laporan keuangan sebagai dasar pengambilan keputusan. Untuk menghasilkan opini audit yang berkualitas, maka seorang auditor harus memiliki skeptisisme professional yang baik.

Skeptisisme profesional merupakan kompetensi dasar yang harus dimiliki oleh seorang auditor agar dapat mendeteksi salah saji atau kecurangan sehingga diharapkan dapat menghasilkan kualitas audit yang baik. Sikap skeptisisme profesional merupakan sikap yang mencakup pemikiran, pertanyaan dan penilaian kritis terhadap bukti audit (AICPA, 2007). Skeptisisme profesional diperlukan untuk memastikan audit dilaksanakan dengan sikap independen untuk mencegah kecurangan yang dapat terjadi.

Lemahnya skeptisisme profesional dianggap sebagai salah satu faktor penyebab kegagalan audit (Beasley et al., 2001). Beasley et al. (2001) menyebutkan bahwa lemahnya skeptisisme profesional auditor berperan dalam 60\% kasus kegagalan audit yang terjadi sepanjang 1987-1997 di Amerika Serikat. Skeptisisme profesional yang dimiliki oleh auditor akan mendorong auditor untuk memperoleh bukti audit yang cukup sehingga dapat dihasilkan opini audit yang tepat. Sebaliknya, jika tingkat skeptisisme profesional rendah maka bukti audit yang dikumpulkan kurang dan terjadi kesalahan pemberian opini audit.

Public Company Accounting Oversight Board (PCAOB) melakukan pemeriksaan rutin setiap tahun terhadap seluruh kantor akuntan publik terdaftar untuk menilai kepatuhannya terhadap Sarbanes-Oxley Act, aturan SEC, dan aturan lain yang terkait dengan kinerja audit terhadap perusahaanperusahaan publik di Amerika Serikat. Laporan Pemeriksaan PCAOB tahun 2017 menunjukkan bahwa tingkat kesalahan auditor Big 4 cukup tinggi, KPMG 50\%, EY, $31 \%$, Deloitte 20\% dan PwC mencapai 24\% (Bramwell, 2019). Skandal-skandal korporasi yang terjadi pada perusahaan terkemuka di dunia seperti Enron, Worldcom dan Arthur Andersen merupakan contoh yang menunjukkan bahwa rendahnya tingkat skeptisisme profesional dapat menyebabkan terjadinya kecurangan (Curtis, 2014). Beberapa kasus kegagalan audit yang terjadi di Indonesia seperti SNP Finance, Garuda Indonesia, dan Jiwasraya juga disebabkan oleh kelalaian auditor dalam menjalankan tugasnya.

Beberapa penelitian terdahulu telah berupaya untuk mengidentifikasi faktorfaktor yang mempengaruhi skeptisisme profesional auditor. Adapun faktor-faktor tersebut antara lain pendidikan, pelatihan, dan pengalaman auditor (Nelson, 2009; Carpenter dan Reimers, 2013; Curtis, 2014; Hurtt et al., 2013; Payne dan Ramsay, 2005; Popova, 2013; Rittenberg, 2012; Figueroa dan Cardona, 2013).

Nelson (2009) menyediakan model pengukuran skeptisisme profesional auditor dengan mempertimbangkan sifat, insentif, pengetahuan, pelatihan, dan pengalaman yang diterima oleh auditor. Kelima faktor ini, yaitu insentif, sifat, pengetahuan, dan pengalaman dan pelatihan juga berdampak pada kemungkinan bahwa penilaian skeptisme profesional menghasilkan tindakan menanggapi penilaian tersebut. Nelson (2009) mengemukakan bahwa perspektif netralitas adalah tema umum standar audit sehubungan dengan tampilan skeptisisme profesional. Nelson (2009) mendefinisikan skeptisisme profesional sebagai penilaian dan keputusan auditor yang mencerminkan penilaian yang lebih tinggi dari risiko bahwa pernyataan tidak benar, tergantung pada informasi yang tersedia untuk auditor. Nelson (2009) berpendapat bahwa definisi ini mendukung keraguan dugaan atas pandangan netral skeptisisme profesional auditor, menyiratkan bahwa auditor yang memiliki skeptisisme profesional yang tinggi memerlukan bukti persuasif yang cukup 
banyak dalam hal kualitas dan atau kuantitas untuk memperoleh keyakinan atas suatu permasalahan. Perspektif yang dikembangkan Nelson (2009) juga menyarankan KAP dapat meningkatkan skeptisisme profesional auditor melalui sistem perekrutan, pelatihan, penilaian kinerja, proses review, sarana pengambilan keputusan, insentif, dan perubahan dalam tugas dan lembaga. Penelitian Nelson (2009) tersebut dikembangkan melalui beberapa penelitian seperti yang dilakukan oleh Hurtt et al. (2013).

Hurtt et al. (2013) memperluas model Nelson (2009) dengan memasukkan moderator dari penilaian skeptisisme profesional dengan memasukkan tiga faktor baru yaitu, karakteristik klien, bukti, dan lingkungan. Hurtt et al. (2013) mengklasifikasikan perbedaan atau sifat individu, pengalaman dan keahlian, pelatihan, motivasi, dan penalaran moral sebagai bagian dari karakteristik individu auditor yang memengaruhi tingkat skeptisisme profesional auditor. Hurtt et al. (2013) menyebutkan bahwa semakin tinggi tingkat pendidikan maka tingkat skeptisisme profesional auditor juga akan meningkat. Namun Hurtt et al. (2013) juga menyatakan bahwa pengaruh pendidikan formal terhadap tingkat skeptisisme profesional tidak dapat dijelaskan secara langsung.

Pendekatan sifat dalam penelitian skeptisisme profesional auditor menunjukkan bahwa skeptisisme profesional adalah sifat yang melekat pada diri seseorang. Hal ini berarti bahwa sumber skeptisisme profesional yang ditampilkan adalah individu yang membentuk sifat (Curtis, 2014). Pendekatan ini berupaya mengukur dan menggunakan kecenderungan respon umum untuk memprediksi penilaian dan keputusan spesifik seorang auditor dalam berbagai konteks audit. Skala yang dikembangkan Hurtt (2010) meliputi ukuran karakteristik umum atau kecenderungan, termasuk keinginan umum auditor untuk belajar sebagai pencarian pengetahuan dan kecenderungan auditor untuk menunda pengambilan keputusan atas masalah penting sampai auditor memperoleh informasi yang memadai untuk mendapatkan keputusan.

Penelitian Glover dan Prawitt (2014) konsisten dengan penelitian Hurtt et al. (2013). Glover dan Prawitt (2014) dalam penelitiannya menyebutkan bahwa penerapan skeptisisme profesional auditor penting untuk meningkatkan kualitas audit. Glover dan Prawitt (2014) menyatakan bahwa pendidikan dan pelatihan yang tepat dapat meningkatkan skeptisisme profesional auditor di tingkat individu. Semakin tinggi tingkat pendidikan dan semakin banyak jam pelatihan yang diikuti maka pengetahuan yang dimiliki akan meningkat searah dengan peningkatan skeptisisme profesional auditor. Meningkatkan skeptisisme profesional auditor melalui pendidikan formal dan pelatihan yang tepat adalah salah satu cara penting untuk meningkatkan kualitas audit. Tetapi kurangnya panduan praktis tentang aplikasi yang sesuai dan dokumentasi terkait skeptisisme profesional auditor dalam literatur profesional akan menyebabkan hasilnya tidak maksimal. Pemahaman bersama antara lembaga akademik, profesional dan regulator akan memungkinkan profesional audit untuk mengidentifikasi, berkomunikasi, dan menggunakan tingkat skeptisisme profesional auditor yang sesuai untuk risiko yang dihadapi.

Penelitian Curtis (2014) menunjukkan bahwa pengalaman pendidikan memiliki pengaruh terhadap peningkatan skeptisisme profesional auditor. Auditor profesional meyakini bahwa skandal akuntansi yang terjadi seperti kasus Enron, Worldcom dan Arthur Andersen cukup baik untuk dimasukkan ke dalam kurikulum Akuntansi dan dapat menjadi media pembelajaran bagi mahasiswa tentang pentingnya skeptisisme profesional auditor. Selain itu, skeptisisme profesional diterapkan lebih efektif melalui peningkatan pengalaman dalam berbagai perikatan audit, tetapi para profesional percaya bahwa pelatihan di tempat kerja dan studi kasus membantu auditor menentukan kualitas yang membentuk pola pikir yang 
mempertanyakan dan penilaian kritis terhadap bukti audit yang diterima. Lebih lanjut, Curtis (2014) juga menjelaskan bahwa setiap individu memiliki keunikan dan tingkat skeptisisme yang berbeda-beda tidak hanya dipengaruhi oleh latar belakang pendidikannya.

Penelitian Payne dan Ramsay (2005) menunjukkan bahwa auditor dengan pengalaman yang lebih banyak justru tingkat skeptisismenya lebih rendah dibandingkan dengan auditor junior. Hal ini mungkin disebabkan karena pada kenyataannya sangat sedikit auditor yang mengalami kecurangan dalam karier mereka, dan dengan demikian penurunan skeptisisme terjadi seiring waktu. Tingkat skeptisisme yang menurun dari waktu ke waktu memiliki implikasi yang tidak baik bagi profesi ini. Ketika auditor mencapai tingkat tanggung jawab yang meningkat, skeptisisme profesional dan kemampuan untuk mengevaluasi bukti audit secara obyektif menjadi lebih penting. Secara keseluruhan, hasil penelitian Payne dan Ramsay (2005) menyarankan perlunya peningkatan fokus pada skeptisisme profesional auditor melalui pelatihan berkelanjutan untuk auditor, serta peringatan secara terus-menerus untuk memelihara skeptisisme profesional yang tepat dan sesuai.

Penelitian Figueroa dan Cardona (2013) konsisten dengan peneltian Payne dan Ramsay (2005) menyebutkan bahwa auditor senior memiliki tingkat skeptisisme profesional yang lebih rendah dibanding auditor junior. Tingkat skeptisisme yang ditunjukkan oleh auditor senior tidak mengalami perubahan yang cukup signifikan pada klien dengan tingkat risiko fraud yang rendah maupun tinggi. Penelitian Figueroa dan Cardona (2013) dilakukan terhadap 156 peserta yang berasal dari auditor yang bekerja di kantor akuntan publik, praktisi independen, dan mahasiswa senior jurusan akuntansi. Pemilihan responden mahasiswa senior atau auditor dengan pengalaman terbatas tidak memiliki perbedaan yang signifikan pada penelitian terkait audit.
Olsen dan Gold (2018) menyatakan bahwa penelitian tentang skeptisisme profesional auditor masih dapat terus dikembangkan dengan menggunakan prespektif baru seperti teori, tingkat kepercayaan, dan penilaian terhadap skeptisisme profesional auditor. Di Indonesia, penelitian tentang skeptisisme profesional auditor juga masih terbatas. Penelitian ini diharapkan dapat menambah bukti empirik mengenai pengaruh faktor-faktor yang diuji pengaruhnya terhadap skeptisisme profesional auditor dan dapat dipergunakan untuk merumuskan saran pengembangan sumber daya manusia di KAP, khususnya dalam penyelenggaraan pelatihan teknis kepada auditor dalam kaitannya dengan usaha pengembangan skeptisisme profesional auditor di KAP. Selain itu, hasil penelitian ini diharapkan dapat digunakan sebagai dasar perumusan saran mengenai pengembangan kurikulum perkuliahan terkait dengan usaha memperkenalkan dan menambah wawasan mahasiswa akuntansi mengenai pentingnya penerapan skeptisisme profesional.

Penelitian ini didasari teori disonansi kognitif (Festinger, 1957) dan menggunakan pendekatan kuantitatif. Jenis data yang digunakan pada penelitian adalah data primer yang diperoleh melalui kuesioner survei yang dikirimkan kepada responden penelitian. Data yang terkumpul diolah secara statistik menggunakan SPSS dengan pengujian analisis regresi berganda untuk mengetahui hubungan antara variabel independen yaitu tingkat pendidikan, pelatihan, dan pengalaman auditor dengan variabel dependen yaitu tingkat skeptisisme profesional auditor.

Bagian berikutnya dari penelitian ini disusun sebagai berikut: bagian 2 berisi tinjauan literatur tentang skeptisisme profesional auditor dan teori yang mendasari penelitian, bagian 3 membahas desain dan metode penelitian secara rinci, bagian 4 berisi hasil analisis dan diskusi tentang pengaruh pendidikan, pelatihan dan pengalaman terhadap skeptisisme profesional 
auditor, dan bagian 5 berisi kesimpulan dan saran untuk penelitian selanjutnya.

\section{TINJAUAN TEORETIS \\ Teori Disonansi Kognitif}

Penelitian ini didasari oleh teori disonansi kognitif. Festinger (1957) menyatakan bahwa adanya disonansi akan menimbulkan ketidaknyamanan psikologis, hal ini akan memotivasi seseorang untuk mengurangi disonansi tersebut dan mencapai konsonansi. Konsonan berarti adanya suatu kesesuaian antara elemen kognitif manusia (Festinger, 1957). Sedangkan hubungan yang disonan sebagaimana yang diungkapkan oleh Festinger (1957:3): “These two elements are in a dissonant relation if, considering these two alone, the observe of one element would follow from the other".

Disonansi diartikan sebagai adanya suatu inkonsistensi dan perasaan tidak menyenangkan yang memotivasi seseorang untuk melakukan suatu tindakan untuk keluar dari ketidaknyamanan tersebut dengan dampak-dampak yang tidak dapat diukur (Festinger, 1957). Disonansi terjadi apabila terdapat hubungan yang bertolak belakang akibat penyangkalan dari satu elemen kognitif terhadap elemen lain. Disonansi juga dapat terjadi apabila auditor terlalu mempercayai bukti audit yang diterima dari kliennya dan kemudian menurunkan tingkat skeptisisme profesional. Sedangkan seorang auditor harus menerapkan skeptisisme profesional yang sesuai dengan risiko yang dihadapi agar dapat mendeteksi terjadinya risiko salah saji dan dapat memberikan opini yang tepat atas laporan keuangan klien.

Kemampuan auditor dalam mendeteksi terjadinya risiko salah saji dapat dilihat dari tingkat pendidikan, jumlah pelatihan yang diperoleh, serta pengalaman yang dimiliki. Teori disonansi kognitif membantu menjelaskan apakah skeptisisme profesional auditor berpengaruh pada ketepatan pemberian opini auditor dilihat dari faktor pendidikan, pelatihan, dan pengalaman, auditor.

\section{Skeptisisme Profesional Auditor}

Skeptisisme terbentuk dari kata "skeptis" yang berasal dari kata dalam bahasan Yunani "skeptikos" yang berarti "bertanya atau reflektif". Skeptisisme dapat juga diartikan sebagai "mencari informasi dengan mempertanyakan". Karakteristik yang berkaitan dengan sikap skeptis meliputi pertanyaan dan observasi yang cermat, menyelidiki refleksi, mencermati lebih dari apa yang sudah terlihat jelas, dan menekan kepercayaan Glover dan Prawitt (2014). Skeptisisme profesional menggabungkan atribut umum yang berkaitan dengan kondisi profesional dalam konteks standar profesional, regulasi, pengawasan, litigasi, negosiasi, pengumpulan bukti dan evaluasi, pertimbangan profesional, transaksi bisnis yang kompleks, dan sebagainya.

Skeptisisme dalam audit merupakan konsep campuran dari aspek epistemik dan psikologis. Aspek epistemik berhubungan dengan cara mengetahui dan memutuskan dengan menggunakan pendekatan apa (positif atau negatif) auditor harus merumuskan perencanaan audit. Sedangkan aspek psikologis berkaitan dengan disposisi auditor dalam mempertanyakan situasi audit tertentu, dan hal ini mengukur sifat questioning mind yang ada pada auditor.

Kecenderungan untuk mempertanyakan keandalan bukti merupakan karakteristik dari penerapan skeptisisme profesional yang tepat dan direkomendasikan oleh pedoman audit internasional. Selain itu, kewaspadaan terhadap petunjuk dan indikator penipuan, bias manajemen, dan melakukan pemeriksaan bukti audit secara kritis adalah karakteristik penting dari skeptisisme profesional. Dewan Standar Audit dan Jaminan Internasional (IASB) berpendapat bahwa skeptisisme profesional meminimalkan risiko kegagalan audit dan kesalahan pemberian opini berdasarkan bukti audit. Auditor tidak boleh mengasumsikan begitu saja bahwa manajemen tidak jujur, tetapi auditor juga tidak boleh mengasumsikan bahwa manajemen sepenuhnya jujur (IAI 2011, SA seksi 230; 
AICPA 2007, AU 230). Dengan demikian, skeptisisme profesional diperlukan oleh auditor untuk mendeteksi kesalahan, salah saji dan indikator penipuan. Tingkat skeptisisme profesional yang sesuai sangat membantu dalam pelaksanaan dan pelaksanaan audit yang tepat.

Munculnya kasus McKesson dan Robbins pada tahun 1938 dianggap awal dari munculnya kata "skeptisisme" dalam audit. Kasus ini membuat Securities and Exchange Comission (SEC) mengajak auditor untuk menerapkan sikap skeptis dalam proses pelaksanaan prosedur audit. Hurtt (2010) menekankan pentingnya auditor dalam menerapkan sikap skeptis secara profesional. Ia mengatakan bahwa skeptisisme profesional dibutuhkan seorang auditor dalam mengelola bukti audit dengan sikap yang sehat.

Banyaknya kegagalan audit pada tahun 1970an membuat SEC menyadari bahwa kegagalan tersebut sebagian besar diakibatkan oleh kurangnya skeptisisme profesional pada auditor. SEC mengungkapkan hal tersebut melalui Accounting Series Release (ASR) \#153 yang menekankan kurangnya skeptisisme profesional tersebut. Kegagalan audit pada tahun 1980an seperti USA vs Arthur Young pada tahun 1984 juga membuat AICPA mengeluarkan standar mengenai skeptisisme profesional. Pada tahun 1988 AICPA menerbitkan SAS No. 53 yang menjadi pengikat resmi antara skeptisisme profesional dan audit.

Terbitnya SAS No. 53 pada tahun 1988 belum cukup untuk mencegah terjadinya kegagalan audit pada tahun 1990an. Oleh karena itu, pada tahun 1997, AICPA menerbitkan SAS No. 82 yang memodifikasi konsep skeptisisme profesional yang diungkapkan pada SAS No. 53. SAS No. 82 menekankan bahwa skeptisisme profesional memiliki peran kunci dari kesuksesan audit. SAS No. 82 juga mengharuskan auditor untuk memberi perhatian lebih pada efek sikap skeptis terhadap tingkat kemunculan salah saji. Maraknya skandal keuangan yang terjadi pada awal abad ke-21 mencerminkan kurangnya penerapan skeptisisme profesional dalam audit. Pada tahun 2002, AICPA menerbitkan SAS No. 99 yang berjudul Consideration of Fraud in a Financial Statement Audit. Standar tesebut memperluas konsep skeptisisme profesional dalam audit dan menekankan tanggung jawab auditor untuk mempertimbangkan kemungkinan adanya kecurangan secara eksplisit dan proaktif.

Glover dan Prawitt (2014) mengungkapkan bahwa seiring dengan meningkatnya kompleksitas transaksi bisnis dan pembaruan dan revisi standar akuntansi secara berkelanjutan, auditor memelihara sikap skeptisisme profesional pada pekerjaannya. Skeptisisme profesional akan mengarahkan auditor untuk menanyakan setiap kondisi yang menunjukkan adanya kemungkinan terjadinya kecurangan (Louwers et al., 2012). Tantangan yang dihadapi auditor adalah untuk memastikan tingkat skeptisisme profesional audit yang tepat dalam melakukan audit. Bias yang tidak disadari, insentif, dan beban kerja, tekanan lingkungan, dan tingkat kepercayaan atau kepercayaan dapat menghambat pelaksanaan skeptisisme profesional (PCAOB).

\section{Faktor-faktor yang Mempengaruhi Skepti- sisme Profesional Auditor}

Penelitian ini dilakukan dengan mengembangkan pendekatan yang dilakukan oleh Hurtt et al. (2013) untuk meninjau literatur tentang faktor yang berpengaruh terhadap skeptisisme profesional auditor. Hurtt et al. (2013) membagi faktor-faktor yang mempengaruhi skeptisisme profesional auditor ke dalam empat kategori besar yaitu: auditor, bukti, klien, dan eksternal. Penelitian ini menggunakan kerangka yang telah dikemukakan Hurtt et al. (2013) karena jauh lebih luas dalam menganalisis faktorfaktor yang mempengaruhi skeptisisme profesional auditor dibandingkan dengan penelitian Nelson (2009). Lebih khusus lagi, Hurtt et al. (2013) membahas bagaimana pengetahuan, pengalaman dan pelatihan auditor, berpengaruh terhadap skeptisisme profesional auditor. 


\section{Pendidikan dan Pelatihan}

Faktor pendidikan dan pelatihan dijelaskan secara berbeda pada penelitian ini. Pendidikan yang dimaksud adalah pendidikan formal yang dimiliki oleh auditor yang diperoleh melalui lembaga pendidikan formal atau sekolah dan mendapatkan gelar secara akademik. Sedangkan pelatihan merupakan upaya peningkatan kompetensi yang diperoleh di luar lembaga pendidikan formal seperti pendidikan profesional berkelanjutan (PPL) yang dipersyaratkan oleh organisasi profesi dan pelatihan profesional lain yang diselenggarakan secara mandiri oleh kantor akuntan.

Auditor dianggap sebagai profesional karena mereka memiliki keahlian unik yang diperoleh melalui pendidikan dan pelatihan, dan mereka juga berkomitmen untuk pembelajaran seumur hidup. Dengan demikian, profesi ini semakin menekankan pentingnya melanjutkan program pendidikan dan pelatihan, yang dilakukan dalam perusahaan akuntansi atau di lembaga lain, untuk membuat auditor mengikuti standar dan teknik terbaru, baik dalam audit dan akuntansi. Program akuntansi profesional adalah salah satu program pendidikan berkelanjutan yang diadakan oleh universitas dan ditujukan untuk lulusan sarjana akuntansi yang ingin mengejar karir sebagai akuntan atau auditor profesional. Secara khusus, kurikulum untuk program akuntansi profesional telah diselaraskan dengan modul CPA.

Penelitian Enes et al. (2016) mengungkapkan bahwa semakin baik tingkat pendidikan yang dimiliki oleh auditor, maka auditor memiliki pertimbangan yang lebih baik. Penelitian yang dilakukan oleh Kalau (2013) juga mengungkapkan hal serupa yaitu pendidikan dan pelatihan dapat memperbaiki pertimbangan auditor dan meningkatkan skeptisisme profesional yang dimiliki.

Penelitian yang dilakukan oleh Gilbertson dan Herron (2014) memberikan usulan bahwa pemahaman mahasiswa akuntansi akan meningkat apabila peraturan terkait ke dalam kurikulum. Dengan demikian, mahasiswa akan lebih memahami peraturan dan kode etik yang berlaku terkait dengan profesi akuntansi, kemudian diharapkan mahasiswa dapat memiliki tingkat skeptisisme profesional yang lebih baik setelah bekerja.

Penelitian Rodgers et al. (2017); dan Sanjaya (2017) mengungkapkan bahwa pelatihan terkait audit berpengaruh signifikan terhadap skeptisisme profesional auditor. Hal ini menunjukkan bahwa semakin banyak pelatihan yang diberikan kepada auditor, maka tingkat skeptisisme profesional yang dimiliki akan membaik. Hal ini karena dengan pelatihan maka auditor akan memperoleh pengetahuan baru tentang perkembangan di bidang audit yang kemudian dapat diaplikasikan pada pekerjaannya. Dengan bertambahnya pengetahuan maka auditor juga akan lebih berhati-hati dan skeptis untuk meminimalisir risiko audit yang timbul.

Berbanding terbalik dengan penelitian sebelumnya, Subhan (2016) menemukan bahwa pelatihan tidak berpengaruh terhadap skeptisisme profesional auditor. Penelitian Subhan (2016) dilakukan terhadap 46 auditor di Inspektorat Kabupaten Sampang. Subhan (2016) menyebutkan bahwa hal tersebut terjadi karena kemungkinan responden mengikuti penjelasan yang diberikan saat pelatihan yang kemudian berdampak pada kurangnya pengetahuan yang dimiliki dan menyebabkan skeptisme profesional pemeriksa rendah.

Penelitian Zahmatkesh dan Rezazaadeh (2017); JuKang et al. (2015); Furiady dan Kurnia (2015); dan Fuad (2015) menunjukkan bahwa kompetensi profesional auditor menunjukkan pengaruh yang signifikan terhadap kualitas audit. Mempekerjakan orang dengan pengalaman tinggi meningkatkan kualitas audit dengan meningkatkan kompetensi profesional auditor; auditor mendapatkan pengetahuan yang lebih dalam dan penilaian yang lebih baik untuk mencapai kualitas audit. Akuntabilitas meningkatkan kinerja auditor dan 
objektivitas auditor memungkinkan mereka untuk beroperasi tanpa pengaruh individu lain. Berdasarkan uraian di atas, diketahui bahwa pendidikan dan pelatihan, keduanya merupakan salah satu faktor penting untuk me- nentukan kompetensi seorang auditor.

Glover dan Prawitt (2014) mengemukakan bahwa pelatihan dan pendidikan adalah faktor-faktor yang disarankan dapat meningkatkan skeptisisme profesional di tingkat individu. Yang penting, auditor dengan gelar pendidikan yang lebih tinggi dan atau lebih banyak jam pelatihan mungkin memiliki pengetahuan yang jauh lebih teoritis tentang topik terkait audit. Pengetahuan yang diperoleh juga dapat digunakan sebagai sarana untuk meningkatkan skeptisisme profesional mereka sehingga mereka dapat membuat penilaian yang lebih baik.

Carpenter et al. (2011) menemukan manfaat tambahan dalam memberikan siswa dengan kursus audit forensik dibandingkan dengan mereka yang tidak memiliki kesempatan yang sama. Secara khusus, mereka menemukan siswa yang telah mengambil kursus menjadi lebih skeptis dalam penilaian mereka tentang risiko penipuan daripada mereka yang tidak mengambil kursus. Oleh karena itu dikemukakan bahwa pendidikan formal, khususnya yang kurikulumnya selaras dengan modul CPA, mampu meningkatkan pengetahuan serta keahlian auditor ketika melaksanakan tugas mereka. Carpenter et al. (2011) berpendapat bahwa pengetahuan yang diperoleh dari program akuntansi profesional berdampak pada pengetahuan auditor, preferensi risiko, dan nilai-nilai.

Siswa dalam program akuntansi profesional memiliki pengetahuan tentang peristiwa, transaksi, dan situasi yang memerlukan perhatian auditor yang lebih baik daripada yang mahasiswa program sarjana. Seiring dengan peningkatan tingkat pengetahuan dan keahlian mereka, skeptisisme profesional juga diperkirakan akan meningkat.

Dessler (2010) mendefinisikan pelatihan sebagai proses mengajarkan keterampilan atau pengetahuan yang dibutuhkan untuk menjalankan pekerjaan tertentu kepada karyawan. Gomes (2010) dalam penelitiannya mengungkapkan bahwa pelatihan merupakan setiap usaha untuk memperbaiki prestasi kerja pada suatu pekerjaan tertentu yang sedang menjadi tanggung jawabnya. Auditor, baik yang baru maupun yang sudah bekerja, perlu mengikuti pelatihan karena adanya tuntutan pekerjaan yang dapat berubah akibat perubahan lingkungan kerja, standar, strategi, dan lain sebagainya. Hal ini bertujuan untuk meningkatkan keterampilan dan wawasan auditor dengan harapan auditor akan lebih mudah dalam melaksanakan tugasnya. Berdasarkan uraian di atas, hipotesis pada penelitian ini adalah:

$\mathrm{H}_{1}$ : Pendidikan memiliki pengaruh terhadap skeptisisme profesional pada auditor.

$\mathrm{H}_{2}$ : Pelatihan memiliki pengaruh terhadap skeptisisme profesional pada auditor.

\section{Pengalaman Auditor}

Variabel berikutnya adalah pengalaman auditor. Pengalaman adalah proses pembelajaran yang meningkatkan potensi pengembangan berperilaku. Pengalaman audit ditunjukkan dengan lamanya waktu bekerja sebagai auditor di kantor akuntan publik. Pengalaman seorang auditor dalam melakukan pemeriksaan laporan keuangan menjadi salah satu faktor yang mempengaruhi tingkat skeptisisme profesional karena auditor yang lebih berpengalaman memiliki kemampuan yang lebih baik untuk mendeteksi adanya kecurangan-kecurangan pada laporan keuangan. Ansah et al., (2002) menyebutkan bahwa auditor yang berpengalaman lebih skeptis dibandingkan auditor yang belum memiliki pengalaman banyak dalam melakukan prosedur audit. Hasil penelitian tersebut mendukung penelitian Libby dan Frederick (1990) yang menunjukkan bahwa pengalaman dan pengetahuan dapat memengaruhi opini auditor.

Auditor yang memiliki pengalaman yang lebih banyak mampu menghasilkan berbagai dugaan atau hipotesis yang lebih 
luas untuk menjelaskan temuan audit. Auditor yang lebih berpengalaman juga lebih mampu menghasilkan hipotesis mengenai motivasi etis yang dapat menjelaskan penilaian dan keputusan manajemen atas tindakan yang dilakukan. Secara khusus, pengalaman yang diperoleh melalui pelatihan dan umpan balik akan mengarahkan auditor untuk menemukan keputusan yang lebih baik.

Penelitian yang dilakukan oleh Payne dan Ramsay (2005) menyebutkan bahwa pengalaman akan mengekspos kemampuan auditor untuk melakukan analisis risiko dan pengambilan keputusan. Semakin beragam pengalaman auditor, maka akan semakin tingggi tingkat kompetensinya dan semakin baik kualitas pengambilan keputusan yang dilakukan.

Payne dan Ramsay (2005) menunjukkan tingkat skeptisisme profesional yang lebih rendah dalam menanggapi risiko penipuan yang rendah, tetapi tidak menunjukkan peningkatan tingkat skeptisisme profesional dalam menanggapi penilaian risiko penipuan yang lebih tinggi. Hal tersebut kemungkinan disebabkan oleh efek pengalaman bahwa pada kenyataannya, sangat sedikit auditor yang mengalami kecurangan dalam karier mereka sehingga dengan demikian terjadi penurunan skeptisisme terjadi seiring waktu.

Asare dan Wright (1997) mengungkapkan bahwa semakin banyak pengalaman yang dimiliki oleh auditor berpengaruh terhadap penilaian risiko dan deteksi kecurangan yang lebih baik. Asare dan Wright (1997) mengungkapkan bahwa pengalaman auditor dalam bidang akuntansi memiliki pengaruh yang signifikan terhadap pertimbangannya dalam menghadapi pekerjaan audit yang kompleks. Auditor yang berpengalaman lebih mudah dalam mendeteksi kemugkinan adanya kecurangan melalui skeptisisme profesional yang tumbuh seiring dengan bertambahnya pengalaman auditor tersebut.

Penelitian sebelumnya di Indonesia mengenai pengaruh pengalaman terhadap skeptisisme profesional auditor yang dilakukan oleh Larimbi et al. (2018) menunjukkan bahwa pengalaman audit memiliki pengaruh signifikan terhadap tingkat skeptisise profesional auditor. Larimbi et al. (2018) mengukur pengalaman menggunakan ukuran lamanya masa kerja responden sebagai auditor. Pada umumnya auditor dengan masa kerja yang lebih lama akan memiliki jabatan yang lebih tinggi sehingga tingkat tanggung jawabnya semakin besar dan tugas yang lebih kompleks. Kompleksitas tugas yang dihadapi akan meningkatkan pengalaman dan pengetahuan auditor. Peningkatan pengetahuan tersebut akan mendorong peningkatan skeptisisme profesional auditor untuk mendeteksi terjadinya kesalahan.

Penelitian lain yang dilakukan oleh Anisma et al. (2011); Anugerah et al. (2011); Samsi dan Riduwan (2013); Silalahi (2013); Winantyadi dan Waluyo (2014); Oktarini dan Ramantha (2016); Barrainkua dan Pike (2018); Zarefar et al. (2016) juga mengungkapkan hal yang sama yaitu pengalaman memiliki pengaruh yang signifikan terhadap tingkat skeptisisme profesional auditor. Semakin lama pengalaman bekerja sebagai auditor maka tingkat skeptisisme profesional yang dimiliki semakin baik. Hal ini terjadi karena auditor memiliki pertimbangan yang lebih baik sehingga lebih berhatihati dalam melaksanakan tugasnya. Selain itu, dengan pertimbangan yang lebih baik, auditor dapat mencapai kualitas audit yang lebih baik.

Berdasarkan uraian di atas, hipotesis ketiga pada penelitian ini adalah:

$\mathrm{H}_{3}$ : Pengalaman memiliki pengaruh terhadap skeptisisme profesional pada auditor 


\section{Teori Disonansi Kognitif (Festinger, 1957)}
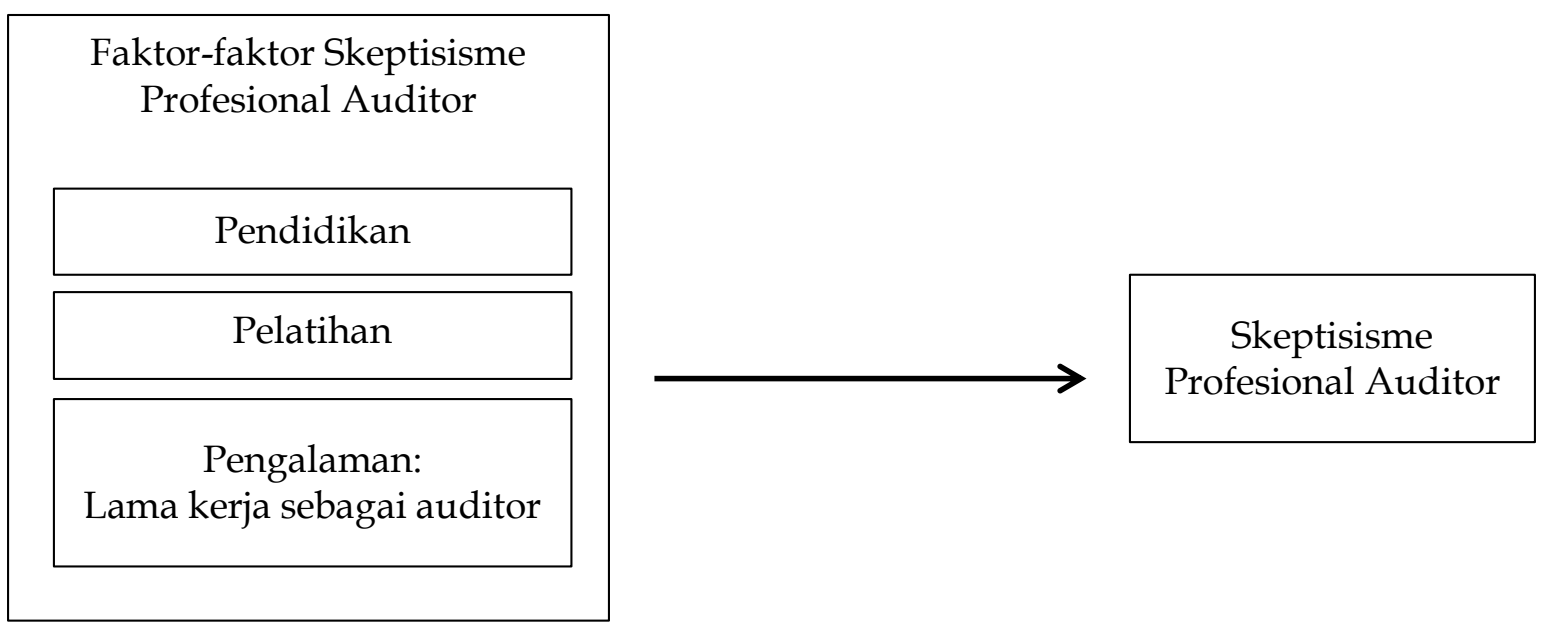

Gambar 1

Rerangka Konseptual

\section{METODE PENELITIAN \\ Pendekatan Penelitian}

Berdasarkan permasalahan yang diteliti, pendekatan yang digunakan dalam penelitian ini adalah pendekatan kuantitatif dengan melakukan pengujian hipotesis. Penelitian kuantitatif merupakan metode yang berlandaskan pada filsafat positivisme yang biasanya digunakan untuk meneliti populasi atau sampel tertentu (Sugiyono, 2011). Sekaran dan Bougie (2016) menjelaskan pendekatan kuantitatif sebagai penelitian menggunakan data-data berbentuk angka yang diolah dan dianalisis secara matematika atau statistik.

\section{Populasi dan Sampel}

Populasi pada penelitian ini adalah seluruh auditor yang bekerja di kantor akuntan publik di Indonesia. Jumlah populasi tidak diketahui. Sampel pada penelitian ini ditentukan sebanyak 200 responden auditor pada KAP Big 4 dan non Big 4 di Indonesia. Jumlah tersebut ditentukan berdasarkan ukuran sampel oleh Roscoe (1975) dalam Sekaran dan Bougie (2016) yaitu jumlah sampel lebih dari 30 dan kurang dari 500 responden. Metode sampling yang digunakan adalah non-probability sampling dengan prosedur convenience sampling atau memilih sampel atau responden yang paling mudah dijumpai. Kuesioner penelitian dikirimkan oleh peneliti kepada responden auditor baik di KAP Big 4 maupun Non Big 4 yang bersedia mengisi kuesioner.

\section{Data Penelitian}

Data yang digunakan dalam penelitian ini adalah data primer. Data primer adalah data yang dikumpulkan peneliti secara langsung untuk tujuan spesifik penelitian (Sekaran dan Bougie, 2016). Data primer diperoleh dari kuesioner yang dikirimkan kepada responden yang merupakan auditor di berbagai KAP di Indonesia, baik big 4 maupun non big 4 dengan jabatan junior auditor, senior auditor, asisten manajer, manajer, senior manajer, hingga partner audit. Penelitian ini dilakukan melalui kuesioner tertutup berupa pertanyaan atau pernyataan yang jawabannya berbentuk skala likert.

\section{Variabel dan Pengukuran}

Variabel dependen adalah variabel yang dijelaskan atau yang dipengaruhi variabel independen, sedangkan variabel independen adalah variabel yang menjelaskan atau 
memengaruhi variabel yang lain (Sugiyono, 2011). Variabel dependen pada penelitian ini adalah skeptisisme profesional auditor. Skeptisisme profesional auditor diukur menggunakan tiga puluh pertanyaan pada kuesioner. Pertanyaan kuesioner terkait skeptisisme profesional auditor diukur menggunakan instrumen yang dikembangkan oleh Hurtt (2010).

Variabel independen penelitian ini adalah pendidikan, pelatihan dan pengalaman. Variabel pendidikan diukur dengan strata pendidikan responden, mulai dari Diploma 3, Diploma 4, S1, S2, dan S3. Setiap tingkatan pendidikan dikodekan dengan angka satu sampai lima. Sedangkan variabel pelatihan diukur dari rata-rata jam pelatihan profesional dalam bidang akuntansi dan auditing yang pernah diikuti oleh responden selama bekerja sebagai auditor dalam satu tahun. Variabel pengalaman auditor diukur dengan masa kerja (length of services) sebagai auditor di kantor akuntan publik yang dipandang akan menambah peningkatan profesionalisme auditor.

\section{Metode Analisis}

Metode analisis yang digunakan untuk menguji hipotesis dalam penelitian ini adalah regresi linear berganda. Analisa regresi berganda digunakan untuk menganalisis pengaruh variabel independen terhadap variabel dependen. Kemudian dilakukan pengecekan dengan menggunakan plot data untuk melihat linearitas data. Persamaan regresi yang digunakan adalah:

$$
\begin{aligned}
& \mathrm{SPA}=a+b 1 \mathrm{Pd}+b 2 \mathrm{Pl}+b 3 \mathrm{Pg}+e \\
& \mathrm{SPA}=\text { Skeptisisme profesional auditor } \\
& \mathrm{Pd}=\text { Pendidikan } \\
& \mathrm{Pl}=\text { Pelatihan } \\
& \mathrm{Pg}=\text { Pengalaman }
\end{aligned}
$$

\section{ANALISIS DAN PEMBAHASAN}

Bagian ini membahas analisis data yang diperoleh selama penelitian. Pembahasan meliputi hasil pengumpulan data, demografi responden, analisis deskriptif, pengujian hipotesis, dan diskusi hasil penelitian.

\section{Analisis Statistik Deskriptif}

Total jumlah kuesioner yang disebarkan adalah sebanyak 200 kuesioner. Terdapat 144 kuesioner yang kembali dan terisi, sedangkan 56 kuesioner lainnya tidak kembali atau tidak terisi. Setelah dilakukan pemeriksaan terhadap kuesioner yang terisi, terdapat 37 kuesioner yang tidak dapat digunakan karena terdapat data yang tidak lengkap atupun terdapat pelanggaran atas indikatorindikator pengendali yang ada pada varibel pelatihan dan skeptisisme profesional auditor.

Berdasarkan data di atas, terdapat 107 kuesioner yang dapat digunakan dalam penelitian ini dengan tingkat pengembalian sebesar $72 \%$ dan tingkat pengembalian yang digunakan sebesar $54 \%$. Tingkat pengembalian ini berada dalam batas yang dapat diterima. Tabel 1 menunjukkan jumlah kuesioner yang disebar, pengembalian hingga yang dapat diolah.

Tabel 1

Data Penelitian

\begin{tabular}{lc}
\hline Jumlah kuesioner yang disebar & 200 \\
Jumlah kuesioner yang tidak terisi atau tidak kembali & 56 \\
Kuesioner yang terisi dan kembali & 144 \\
Kuesioner yang digugurkan & 37 \\
Kuesioner yang digunakan & 107 \\
Tingkat pengembalian & $72 \%$ \\
Tingkat pengembalian yang digunakan & $54 \%$ \\
\hline Sumber:
\end{tabular}

Sumber: Data primer, diolah 
Tabel 2 menunjukkan hasil statistik deskriptif data yang diperoleh pada penelitian. Berdasarkan Tabel 2 diketahui bahwa penelitian dilakukan terhadap 107 data pengamatan. Nilai minimum dan maksimum untuk variabel pendidikan, pelatihan, pengalaman, dan skeptisisme professional auditor merujuk pada jawaban responden penelitian. Variabel pendidikan mencapai nilai minimum 1. Hal ini menunjukkan bahwa minimal pendidikan responden penelitian adalah kelompok 1 yaitu D3 Akuntansi.Nilai maksimum yang dicapai variabel pendidikan adalah 5 yang merujuk pada kategori pendidikan Doktor Akuntansi. Nilai rata-rata pendidikan adalah 3, artinya rata-rata tingkat pendidikan responden adalah strata satu Akuntansi. Latar belakang pendidikan responden penelitian cukup homogen, dimana mayoritas responden penelitian adalah lulusan strata satu. Hal ini terlihat dari nilai standar deviasi yang cukup kecil yaitu 0,922 . Nilai minimum 0 atas variabel pelatihan menunjukkan nilai terendah atas jawaban responden terhadap pertanyaan pada kuesioner penelitian.

Tabel 2

Statistik Deskriptif

\begin{tabular}{lccccc}
\hline \hline & N & Min & Max & Mean & Std. Deviation \\
\hline Pendidikan & 107 & 1 & 5 & 3,35 & 0,922 \\
Rata-rata jam pelatihan & 107 & 0 & 40 & 3,62 & 4,803 \\
Pengalaman & 107 & 1 & 30 & 7,56 & 7,095 \\
Skeptisisme Profesional & 107 & 4 & 6 & 4,95 & 0,430
\end{tabular}

Auditor

Sumber: Data primer, diolah

Terdapat responden penelitian yang sama sekali tidak pernah menerima pelatihan di KAP tempatnya bekerja. Variabel pelatihan mencapai nilai maksimum 40 yang menunjukkan bahwa terdapat responden yang memperoleh 40 jam pelatihan audit per tahun. Sedangkan rata-rata jam pelatihan untuk seluruh responden adalah 3,62 jam per tahun. Sebaran data untuk variabel cukup jauh berkisar antara 0 sampai dengan 40 jam pelatihan per tahun, menghasilkan standar deviasi yang juga cukup besar yaitu mencapai 4,8.

Variabel pengalaman juga diukur dalam hitungan jumlah tahun responden berpraktik sebagai auditor. Pengalaman responden penelitian berkisar antara satu tahun hingga tiga puluh tahun, dengan rata-rata pengalaman bekerja sebagai auditor untuk seluruh responden 7,5 tahun. Sebaran data yang cukup bervariasi menghasilkan simpangan baku yang cukup besar yaitu mencapai 7,1 .
Variabel berikutnya adalah skeptisisme profesional auditor. Variabel skeptisisme profesional auditor ditanyakan dalam skala likert yang terdiri dari tiga puluh pertanyaan dengan skala antara satu sampai dengan enam. Nilai minimum yang diperoleh adalah 4 poin dan maksimumnya adalah 6 poin. Seluruh pertanyaan kuesioner telah diuji validitas dan reliabilitasnya.

\section{Uji Validitas dan Reliabilitas}

Uji validitas digunakan untuk mengukur sah atau tidaknya suatu kuesioner. Kuesioner dinyatakan balid jika pertanyaan pada kuesioner mampu untuk mengungkapkan sesuatu yang akan diukur oleh kuesioner tersebut. Jika jawaban seseorang terhadap pertanyaan yang terdapat dalam kuesioner tersebut adalah konsisten atau stabil dari waktu ke waktu (Ghozali, 2018). Uji validitas dilakukan dengan melakukan korelasi bivariate antara masing-masing skor indikator dengan total skor konstruk. Hasil 
uji validitas diketahui bahwa seluruh pertanyaan terkait dengan variabel skeptisisme profesional auditor menunjukkan korelasi yang signifikan dengan nilai konstruk. Sehingga dapat disimpulkan bahwa seluruh indikator pertanyaan adalah valid.

Reliabilitas adalah alat untuk mengukur suatu kuesioner yang merupakan indikator variabel atau konstruk. Suatu kuesioner dikatakan andal atau stabil jika jawaban responden terhadap setiap pernyataan adalah konsisten dari waktu ke waktu (Ghozali, 2018). Ukuran reliabilitas yang digunakan pada penelitian ini adalah Cronbach Alpha. Secara umum, suatu variabel dinyatakan reliabel jika nilai Cronbach Alpha bernilai lebih dari 0,70 (Nunnally, 1994 dalam Ghozali, 2018).

Tabel 3

Hasil Uji Reliabilitas

\begin{tabular}{lcc}
\hline Variabel & Cronbach Alpha & Keterangan \\
\hline Skeptisisme Profesional Auditor $(\mathrm{Y})$ & 0,928 & Reliabel \\
\hline Sumber: Data primer, diolah. & &
\end{tabular}

Berdasarkan Tabel 3 di atas, diketahui bahwa nilai Cronbach Alpha variabel skeptisisme profesional auditor memiliki nilai diatas 0,70, maka dapat disimpulkan bahwa variabel skeptisisme profesional auditor lolos dalam uji reliabilitas dan dinyatakan reliabel.

\section{Uji Asumsi Klasik}

Sebelum melakukan pengujian hipotesis, terlebih dahulu dilakukan pengujian terhadap asumsi klasik untuk menguji apakah terjadi penyimpangan data. Data penelitian yang memenuhi uji asumsi klasik akan menghasilkan hasil regresi yang ideal atau tidak bias. Dalam asumsi klasik terdapat beberapa pengujian yang harus dilakukan, yakni Uji Normalitas, Uji Multikolonieritas, Uji Heterosdastisitas, dan Uji Autokorelasi.

Nilai signifikansi yang digunakan pada penelitian ini adalah $5 \%$ dengan tingkat kepercayaan $95 \%$.

\section{Uji Normalitas}

Uji normalitas bertujuan untuk mengetahui apakah dalam model regresi, variabel residual memiliki distribusi normal atau tidak. Model data yang baik adalah berdistribusi normal atau mendekati normal. Untuk melihat data berdistribusi normal dilakukan dengan memperhatikan normal probability plot pada scatter plot berdistribusi normal.

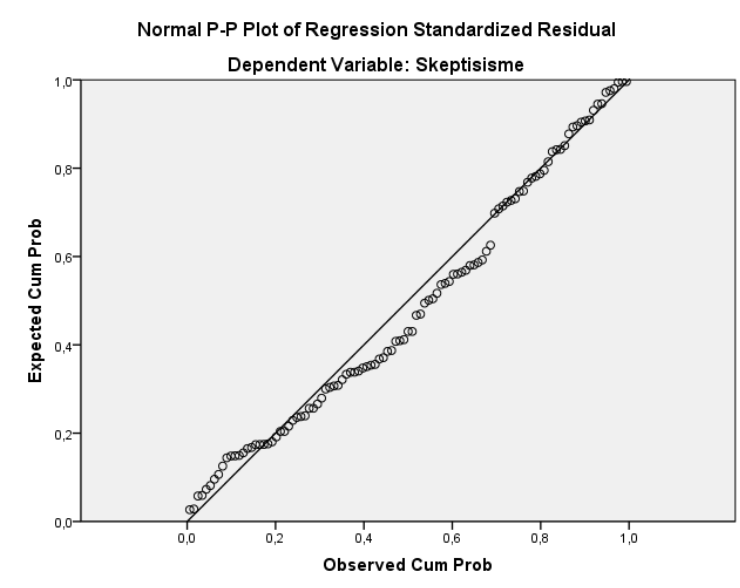

Gambar 2

Grafik Uji Normalitas 
Berdasarkan grafik di atas, diketahui bahwa seluruh data pada penelitian berdistribusi normal, karena semua data menyebar membentuk garis lurus diagonal maka data tersebut memenuhi asumsi normalitas. Selain dengan melihat grafik, normalitas data juga diukur menggunakan uji Kolmogrov-Smirnov pada alpha sebesar $5 \%$. Berdasarkan uji Kolmogorov-Smirnov diperoleh nilai signifikansi 0,065 yang berarti bahwa nilai p-value lebih besar dibanding 0,05 sehingga dapat disimpulkan bahwa data berdistribusi normal.

\section{Uji Multikolinearitas}

Uji multikolinearitas bertujuan untuk menguji apakah dalam model regresi terdapat korelasi antar variabel bebas. Model regresi yang baik seharusnya tidak terjadi korelasi di antara variabel bebas. Deteksi multikolinearitas dengan melihat tolerance dan variance inflation factor (VIF). Nilai yang umum dipakai adalah nilai tolerance 0,10 atau sama dengan nilai VIF di atas 10. Tingkat tolerance 0,10 menandakan telah terjadi masalah multikolinieritas sebesar 0,95 (Ghozali, 2018).

Tabel 4

Hasil Uji Multikolinieritas

\begin{tabular}{|c|c|c|}
\hline Variabel & Tolerance & VIF \\
\hline Pendidikan & 900 & 1,112 \\
\hline Pelatihan & ,923 & 1,084 \\
\hline Pengalaman & ,834 & 1,199 \\
\hline
\end{tabular}

Sumber: Data primer, diolah.

Uji multikolinieritas yang dilakukan dalam penelitian ini menunjukkan bahwa semua nilai VIF dari data yang dikumpulkan di bawah 10 dan nilai toleransinya lebih besar dari 0,1. Dengan demikian, disimpulkan bahwa tidak terjadi adanya multikolinieritas yang dapat menyebabkan ketidakstabilan dalam analisis regresi. Oleh karena itu data kemudian dapat digunakan untuk analisis regresi linier berganda lebih lanjut.

\section{Uji Heteroskedastisitas}

Uji heteroskedastisitas bertujuan untuk menguji apakah data dalam model regresi terjadi ketidaksamaan variance dari residual satu pengamatan ke pengamatan lain. Jika variance dari residual satu pengamatan ke pengamatan lain tetap, maka disebut homoskedastisitas dan jika berbeda disebut heteroskedastisitas. Model regresi yang baik adalah yang homoskedastisitas atau tidak terjadi heteroskedastisitas (Ghozali, 2018). Heteroskedastisitas dapat diuji melalui grafik plot. Jika scatterplot menunjukkan pola tertentu, maka ada kemungkinan telah terjadi masalah heteroskedastisitas pada data penelitian.

Berdasarkan grafik scatterplot Gambar 3, terlihat bahwa titik-titik menyebar secara acar dan tersebar diantara sumbu $\mathrm{X}$ dan $\mathrm{Y}$. Hal ini menunjukkan bahwa tidak terjadi masalah heteroskedastisitas pada data penelitian.

\section{Uji Autokorelasi}

Uji autokorelasi bertujuan untuk mengetahui apakah dalam suatu model regresi terdapat korelasi antara pengganggu pada periode $t$ dengan kesalahan pada periode $\mathrm{t}-1$ (sebelumnya). Alat analisis yang digunakan adalah uji Durbin-Watson. Uji Durbin-Watson hanya digunakan untuk autokorelasi tingkat satu dan mensyaratkan adanya konstanta dalam model regresi. Model regresi yang baik adalah model regresi yang bebas dari autokorelasi (Ghozali, 2018). 


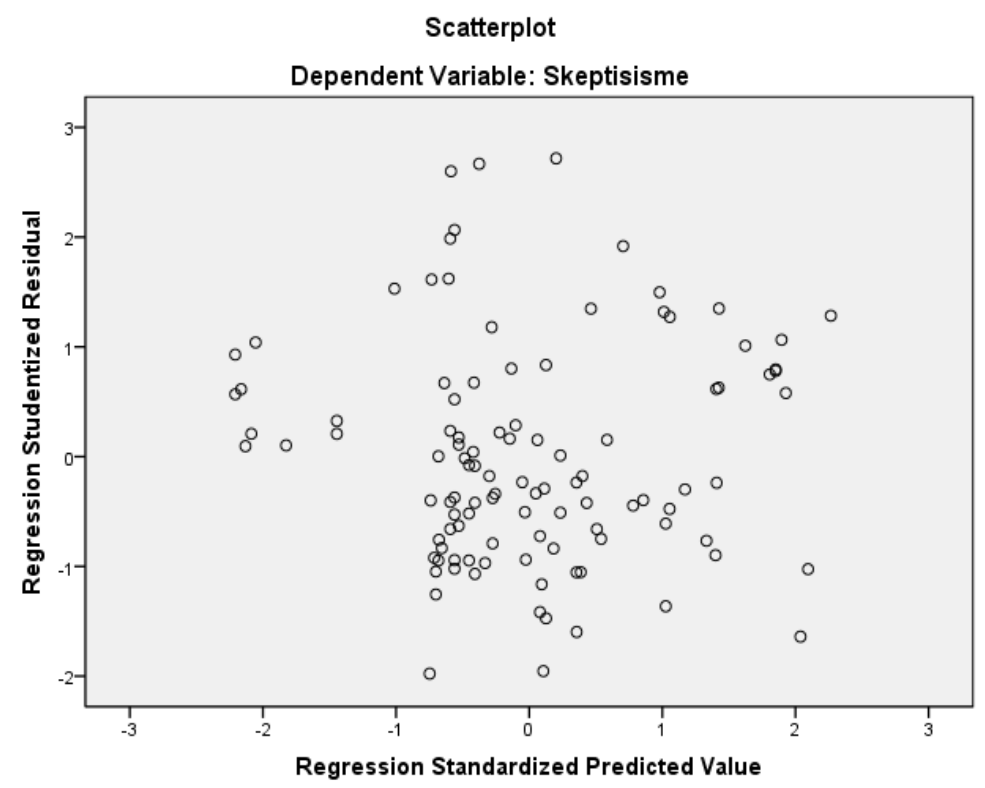

Gambar 3

Scatterplot Uji Heteroskedastisitas

Tabel 5

Hasil Uji Autokorelasi

\begin{tabular}{ccc}
\hline \hline Model & $\mathbf{R}^{2}$ & DW \\
\hline 1 & 0,599 & 1,902 \\
\hline
\end{tabular}

Sumber: Data primer, diolah

Berdasarkan Tabel 5 di atas, diketahui nilai DW sebesar 1,902 dibandingkan dengan $\mathrm{DW}$ tabel $\mathrm{dU}=1.7428$. Nilai DW lebih besar dari batas atas (dU) dan kurang dari 4 - dU $(4-1,7428=2,2572)$, maka dapat disimpulkan bahwa tidak terjadi autokorelasi pada model regresi.

\section{Analisis Regresi Berganda}

Persamaan regresi berganda ini dilakukan untuk mengujii pengaruh pendidikan, pelatihan dan pengalaman ter hadap skeptisisme profesional auditor. Hasil analisis regresi linier berganda disajikan pada Tabel 6.

Tabel 6

Tabel Hasil Regresi Berganda

\begin{tabular}{lrrrr}
\hline \multicolumn{1}{c}{ Variabel } & B & \multicolumn{1}{c}{ Beta } & \multicolumn{1}{c}{ t-hitung } & \multicolumn{1}{c}{ Sig. } \\
\hline Konstanta & 4,177 & & 32,151 &, 000 \\
Pendidikan & 0,197 & 0,421 & 5,064 &, 000 \\
Rata-rata jam pelatihan/th & $-0,008$ & $-0,092$ & $-1,119$ & 0,266 \\
Pengalaman & 0,020 & 0,325 & 3,757 & 0,000 \\
\hline
\end{tabular}

R Square : 0,599

$F_{\text {test }} \quad: 19,166 \quad F_{\text {table }}: 2,69 \quad$ Sig: 0,000

Uji F dilakukan untuk menemukan efek dari semua variabel independen terhadap variabel dependen. Model penelitian juga dapat disimpulkan signifikan karena hasil tes menunjukkan bahwa nilai F-statistik adalah 0,000 . Ini mendukung aturan praktis 
bahwa jika nilai F-statistik kurang dari nilai a $(0,000<0,5)$, itu berarti bahwa model penelitian signifikan.

Uji-t untuk setiap variabel independen dilakukan untuk mengukur signifikansi korelasinya dengan variabel dependen skeptisisme profesional auditor. Hasil penelitian menunjukkan bahwa variabel independen tingkat pendidikan dan pengalaman signifikan positif dalam mempengaruhi skeptisisme profesional auditor. Di sisi lain, rata-rata jam pelatihan yang diikuti oleh auditor per tahun tidak berpengaruh signifikan terhadap tingkat skeptisisme profesional auditor.

Berdasarkan analisis uji regresi berganda, persamaan model regresi untuk penelitian ini dapat dihasilkan sebagai berikut:

$$
\begin{aligned}
\mathrm{SPA}= & 4,177+0,197 \mathrm{Pd}+(-0,008) \mathrm{Pl}+ \\
& 0,020 \mathrm{Pg}+e
\end{aligned}
$$

Persamaan regresi di atas menunjukkan koefisien 4,177 sebagai nilai konstan dan diikuti oleh dua koefisien variabel independen yang memiliki pengaruh positif terhadap variabel dependen. Dua variabel independen adalah X1 (Pendidikan) dan X3 (Pengalaman). Hal ini berarti bahwa setiap variabel rata-rata jam pelatihan meningkat, akan memberikan efek positif terhadap tingkat skeptisisme profesional auditor. Setiap peningkatan satu poin pada variabel independen akan menghasilkan skeptisisme professional auditor yang lebih baik. Berbeda dengan variabel independen $X_{2}$ (Ratarata Jam Pelatihan per Tahun) yang memiliki koefisien negatif. Hal ini berarti bahwa setiap variabel rata-rata jam pelatihan meningkat, akan memberikan efek negatif terhadap tingkat skeptisisme profesional auditor.

\section{Pengaruh Pendidikan terhadap Tingkat Skeptisisme Profesional Auditor}

$\mathrm{H}_{1}$ bertujuan untuk menguji apakah tingkat pendidikan berpengaruh terhadap tingkat skeptisisme profesional auditor.
Konsisten dengan harapan penelitian, hasil penelitian menunjukkan bahwa tingkat pendidikan berpengaruh secara signifikan positif terhadap tingkat skeptisisme profesional auditor yang berarti bahwa seseorang dengan tingkat pendidikan yang lebih tinggi akan memiliki tingkat skeptisisme profesional yang lebih baik dibandingkan auditor dengan tingkat pendidikan yang lebih rendah. Hasil penelitian juga menunjukkan bahwa pendidikan formal mampu membentuk sikap dan perilaku auditor. Oleh karena itu, sangat disarankan agar auditor memiliki tingkat pendidikan yang lebih tinggi untuk memperdalam pengetahuan mereka dan mempertajam keterampilan mereka dalam audit. Secara keseluruhan, temuan kami mendukung perspektif tentang bagaimana tingkat pendidikan yang lebih tinggi secara positif mempengaruhi tingkat skeptisisme profesional auditor (Curtis (2014); Glover dan Prawitt (2014); Barnes dan Huan (2006); Enes et al. (2016); Kalau (2013); Zahmatkesh dan Rezazaadeh (2017); JuKang et al. (2015); Furiady dan Kurnia (2015); dan Fuad (2015).

\section{Pengaruh Pelatihan terhadap Tingkat Skeptisisme Profesional Auditor}

H2 bertujuan untuk menguji apakah rata-rata jam pelatihan berpengaruh terhadap tingkat skeptisisme profesional auditor. Berbeda dengan harapan penelitian, hasil penelitian menunjukkan bahwa pelatihan tidak berpengaruh terhadap tingkat skeptisisme profesional auditor yang berarti bahwa seseorang dengan rata-rata jam pelatihan per tahun yang lebih banyak akan memiliki tingkat skeptisisme profesional yang lebih rendah dibandingkan auditor dengan rata-rata jam pelatihan yang lebih tinggi. Hasil penelitian tidak mendukung penelitian sebelumnya yang dilakukan oleh Rodgers et al. (2017); dan Sanjaya (2017), tetapi mendukung hail penelitian Subhan (2016). Hasil penelitian mungkin disebabkan oleh karena auditor tidak mengikuti pelatihan dengan sungguh-sungguh sehingga tambahan pemahaman yang didapatkan 
tidak maksimal. Pelatihan untuk auditor biasanya dilakukan pada masa-masa sibuk (peak season) sehingga konsentrasi auditor terbagi antara penyelesaian audit klien dengan pelaksanaan pelatihan. Penting bagi bagian pengembangan SDM di KAP untuk memperhatikan waktu pelaksanaan pelatihan bagi auditor agar diperoleh tambahan pengetahuan yang maksimal oleh auditor.

Auditor yang ditugaskan untuk melaksanakan prosedur audit terhadap klien harus memiliki kompetensi dan kemampuan teknis yang cukup baik dalam bidang akuntansi maupun auditing. Hal tersebut dibutuhkan agar auditor dapat melaksanakan tugasnya dalam menjalankan prosedur audit dengan baik. Kompetensi dan kemampuan teknis auditor dapat diperoleh tidak hanya melalui pendidikan formal maupun pelatihan teknis di bidang akuntansi dan auditing. Pelatihan teknis memberikan wawasan dan kemampuan teknis yang dibutuhkan oleh seorang auditor agar dapat meningkatkan performa kerja dalam melaksanakan prosedur audit. Dalam melaksanakan prosedur audit, auditor dituntut untuk memiliki sikap skeptisisme profesional agar dapat mendeteksi adanya indikasi kecurangan yang dilakukan secara sengaja maupun tidak sengaja oleh klien.

\section{Pengaruh Pengalaman terhadap Tingkat Skeptisisme Profesional Auditor}

Seperti yang diharapkan pada $\mathrm{H}_{3}$ bahwa pengalaman memiliki pengaruh terhadap tingkat skeptisisme profesional auditor, hasil penelitian menunjukkan bahwa pengalaman memiliki pengaruh positif terhadap tingkat skeptisisme profesional auditor. Penerimaan atas hipotesis ini mengindikasikan bahwa jabatan dan lama seseorang bekerja sebagai auditor memberikan wawasan lebih dan menjadikan auditor tersebut lebih skeptis dalam melaksanakan pekerjaan audit. Auditor yang memiliki lebih banyak pengalaman akan lebih mudah mendeteksi adanya indikasi kecurangan yang dilakukan oleh klien. Hasil penelitian ini konsisten dengan penelitian Ansah (2002); Libby dan Frederick
(1990); Payne dan Ramsay (2005); Asare dan Wright (1997); Anisma et al. (2011); Anugerah et al. (2011); Samsi dan Riduwan (2013); Silalahi (2013); Winantyadi dan Waluyo (2014); Oktarini dan Ramantha (2016); Barrainkua dan Pike (2018); Larimbi et al., (2018); dan Zarefar et al. (2016) yang mengungkapkan bahwa auditor berpengalaman memiliki kemampuan lebih baik dalam mendeteksi kecurangan.

Pengalaman audit merupakan pengalaman auditor dalam melaksanakan audit laporan keuangan baik dari segi lamanya waktu, maupun banyaknya penugasan yang pernah dilakukan. Auditor dengan jam terbang yang lebih banyak pasti sudah memiliki pengalaman yang lebih dibandingkan dengan auditor yang jam terbangnya kurang. Semakin banyak jam terbang yang dimiliki oleh seorang auditor, semakin banyak pula pengalaman yang diperoleh auditor. Pengalaman tersebut memiliki peran penting dalam pelaksanaan prosedur audit dan penggunaan professional judgement yang dilakukan oleh auditor. Sebaliknya, kurangnya pengalaman dapat menghambat penerapan skeptisisme profesional oleh auditor.

\section{SIMPULAN DAN SARAN}

Penelitian ini menguji pengaruh pendidikan, pelatihan, dan pengalaman auditor terhadap skeptisisme profesional auditor di Indonesia. Hasil penelitian menunjukkan bahwa pendidikan, pelatihan, dan pengalaman memiliki pengaruh signifikan terhadap tingkat skeptisisme profesional auditor. Hasil penelitian mendukung penelitian yang dilakukan oleh Asare dan Wright (1997); Payne dan Ramsay (2005); Curtis (2014); dan Glover dan Prawitt (2014). Hasil penelitian ini merupakan aplikasi dari teori disonansi kognitif dan menjelaskan apakah skeptisisme profesional auditor berpengaruh pada ketepatan pemberian opini auditor dilihat dari faktor pendidikan, pelatihan, pengalaman, dan situasi audit yang dihadapi oleh auditor. Kendala waktu telah membatasi penulis untuk mengumpulkan lebih banyak 
respons, meskipun tingkat respons telah mencapai $72 \%$. Ini dapat ditingkatkan dengan memperpanjang periode penelitian. Selain itu, penelitian ini hanya menganalisis pengaruh tingkat pendidikan, rata-rata jam pelatihan per tahun, dan pengalaman auditor terhadap tingkat spektisisme profesional auditor.

Saran untuk penelitian lebih lanjut adalah meningkatkan jumlah responden untuk penelitian dan jenis proyek yang dianalisis untuk mendapatkan gambaran yang lebih luas dan lebih bervariasi atas faktor-faktor yang mempengaruhi tingkat skeptisisme profesional auditor. Selain itu, penelitian selanjutnya dapat dilakukan atas faktor-faktor lain yang mempengaruhi skeptisisme profesional auditor seperti gender, situasi audit yang dihadapi, dan mempertimbangkan rotasi auditor. Selain itu, ukuran pengalaman pada penelitian ini yang hanya terbatas pada jabatan dan lama waktu seseorang bekerja sebagai auditor juga dapat diubah menggunakan ukuran lain yang lebih baik.

\section{DAFTAR PUSTAKA}

AICPA. 2007. Due Profesional Care in the Performance of Work. In PCAOB Standards and Related Rules (p. Section 230). New York.

Anisma, Y., Z. Abidin, dan Christina. 2011. Faktor-Faktor yang Mempengaruhi Sikap Skeptisme Profesional Seorang Auditor pada KAP di Sumatera. Pekbis Jurnal 3(2): 490-497.

Ansah, S., G. Moyes, P. Oyelere, dan D. Hay. 2002. An Empirical Analysis of the Likelihood of Detecting Fraud in New Zealand. Managerial Auditing Journal 17(4): 192 - 204

Anugerah, R., R. N. Sari, dan R. M. Frostiana. 2011. The Relationship between Ethics, Expertise, Audit Experience, Fraud Risk Assessment and Audit Situational Factors and Auditor Professional Skepticism. International Symposium on Finance and Accounting.
Asare, S. dan A. Wright. 1997. Hypothesis Revisions Strategies in Conducting Analytical Procedures. Accounting. Organizations and Society 22(8): 737-755.

Barnes, P. dan H. Huan. 2006. The auditor's going concern decision: Some UK evidence concerning independence and competence. Journal of Business Finance $\mathcal{E}$ Accounting. 20: 213 - 228. 10.1111/j.14685957.1993.tb00660.x.

Barrainkua, I. dan M. Pike. 2018. The influence of auditors' professionalism on ethical judgement: Differences among practitioners and postgraduate students. Revista de Contabilidad 21(2): 176-187.

Beasley, M., J. Carcello, dan D. Hermanson. 2001. Top 10 Audit Deficiencies. Journal of Accountancy 191: 63-66.

Bramwell, J. 2019. At Least EY's 2017 PCAOB Inspection Report Is Not as Not Good as KPMG's. Retrieved January 6, 2020, from Goingconcern website: https:// goingconcern.com/at-least-eys-2017pcaob-inspection-report-is-not-as-notgood-as-kpmgs/.

Carpenter, T., D. C. Durtschi dan L. M. Gaynor. 2011. The Incremental Benefits of a Forensic Accounting Course on Scepticism and Fraud-related Judgments. Issues in Accounting Education, 26(1): 1-21.

Carpenter, T. D. dan J. L. Reimers. 2013. Profesional Skepticism: The Effects of a Partner's Influence and the Level of Fraud Indicators on Auditors' Fraud Judgments and Actions. Behavioral Research in Accounting 25(2): 45-69.

Curtis, R. K. 2014. Breaking the Barrier - An Examination into the Current State of Profesional Skepticism. Honors Scholar Theses 340: 1-28.

Dessler, G. 2010. Manajemen Sumber Daya Manusia. PT. Prenhallindo. Jakarta.

Enes, E. F., B. J. M. Almeida, A. M. F. G. da Silva, F. P. Carvalho, dan J. M. M. Simoes. 2016. Education as a contribution to reduce the audit expectation 
gap: The Portuguese case. Tékhne 14(1). 10-19.

Festinger, L. 1957. A theory of cognitive dissonance. Stanford University Press.

Figueroa, C. B. R. dan R. Cardona. 2013. Does Experience Affect Auditors Professional Judgement? Evidence from Puerto Rico. Accounting and Taxation Journal 5(2): 1332.

Fuad, K. 2015. Pengaruh independensi, kompetensi, dan prosedur audit terhadap tanggungjawab dalam pendeteksian fraud. Jurnal Dinamika Akuntansi 7(1): 10-17.

Furiady, O. dan R. Kurnia. 2015. The Effect of Work Experiences, Competency, Motivation, Accountability and Objectivity towards Audit Quality. Procedia - Social and Behavioral Sciences (211), 25: 328-335.

Ghozali, I. 2018. Aplikasi Analisis Multivariate Dengan Program IBM SPSS 25. Edisi 9. BP Universitas Diponegoro. Semarang.

Gilbertson, D. dan T. Herron. 2014. Including audit regulation in the accounting curriculum. Research in Accounting Regulation 26(1): 118-131.

Glover, S. M. dan D. Prawitt. 2014. Enhancing Auditor Professional Skepticism: The Professional Skepticism Continum. Current Issues in Auditing (2): 1-10.

Gomes, F. C. 2010. Manajemen Sumber Daya Manusia, Edisi 2. Cetakan 4, Andi. Yogyakarta.

Hurtt, R. K. 2010. Development of a Scale to Measure Profesional Skepticism. AUDITING: A Journal of Practice dan Theory 29(1): 149-171. https://doi.org/ 10. 2308/aud.2010.29.1.149.

Hurtt, R. K., H. Brown-Liburd, C. E. Earley, dan G. Krishnamoorthy. 2013. Research on Auditor Profesional Skepticism: Literature Synthesis and Opportunities for Future Research. AUDITING: A Journal of Practice dan Theory 32(1): 45-97. https://doi.org/10.2308/ajpt-50361.

IAI. 2011. Standar Profesional Akuntan Publik (SPAP). Salemba Empat. Jakarta.

JuKang, Y., A. Trotman, dan K. Trotman. 2015. The effect of an Audit Judgment
Rule on audit committee members' professional skepticism: The case of accounting estimates. Accounting, Organization and Society 46: 59-76.

Kalau, A. A. 2013. Pengaruh Kompetensi, Independensi, dan Skeptisisme Profesional Auditor Internal Terhadap Kualitas Audit (Survey Persepsi Auditor Inspektorat Kota Ambon). Cita Ekonomika. 7(2): 257-261.

Larimbi, D., B. Subroto, dan Rosidi. 2018. Pengaruh faktor-faktor personal terhadap skeptisisme profesional auditor. Jurnal Ekuitas 17(1): 89-107. http:// dx.doi.org/10.24034/j25485024.y2013.v 17.i1.267.

Libby, R. dan D. Frederick. 1990. Experience and the Ability to Explain Audit Findings. Journal of Accounting Research, 28(2): 348-367.

Louwers, T., R. Ramsay, D. Sinason, dan J. Strawser. 2012. Auditing and Assurance Service. Mc Graw Hill. New York.

Nelson, M. W. 2009. A model and literature review of profesional skepticism in auditing. AUDITING: A Journal of Practice dan Theory 28(2): 1-34. https:// doi.org/10.2308/aud. 2009.28.2.1.

Oktarini, K. dan I. W. Ramantha. 2016. Pengaruh Pengalaman Kerja Dan Kepatuhan Terhadap Kode Etik Pada Kualitas Audit Melalui Skeptisisme Profesional Auditor. E-Jurnal Akuntansi, 15(1): 754-783.

Olsen, C. dan A. Gold. 2018. Future research directions at the intersection between cognitive neuroscience research and auditors' professional skepticism. Journal of Accounting Literature 41: 127-141.

Payne, E. A. dan R. J. Ramsay. 2005. Fraud risk assessments and auditors' profesional skepticism. Managerial Auditing Journal, 20 (3): 321-330. https:// doi.org/ 10.1108/02686900510585636.

Popova, V. 2013. Exploration of skepticism, client-specific experiences, and audit judgments. Managerial Auditing Journal, 28(2): 140-160. https://doi.org/10.1108/ 02686901311284540. 
Rittenberg, L. E. 2012. Comments on Governance, Profesional Skepticism, and Auditor Independence. Retrieved January 4, 2020, from PCAOB website: http://pcaobus.org/Rules/Rulemaking/Dock et037/ps_Rittenberg.pdf

Rodgers, W., G. N. Mubako, dan L. Hall. 2017. Knowledge management: The effect of knowledge transfer on professional skepticism in audit engagement planning. Computers in Human Behavior. 70: 564-574.

Samsi, N. dan B. Riduwan. 2013. Pengaruh Pengalaman Kerja, Independensi, dan Kompetensi Terhadap Kualitas Audit: Etika Auditor sebagai Variabel Pemoderasi. Jurnal Ilmu dan Riset Akuntansi 1(2): 1-15.

Sanjaya, A. 2017. Pengaruh Skeptisisme Profesional, Independensi, Kompetensi, Pelatihan Auditor, dan Resiko Audit Terhadap Tanggung Jawab Auditor Dalam Mendeteksi Kecurangan. Jurnal Akuntansi Bisnis 15(1): 41-55.

Sekaran, U. dan R. Bougie. 2016. Research Methods for Business: A Skill-Building Approach (7th Edition). John Wiley \& Sons Ltd. New Jersey.
Silalahi, S. P. 2013. Pengaruh Etika, Kompetensi, Pengalaman Audit dan Situasi Audit terhadap Skeptisisme Profesional Auditor. Jurnal Ekonomi 21(3): 1-21.

Subhan. 2016. Faktor-faktor yang mempengaruhi skeptisme profesional. AKTIVA Jurnal Akuntansi dan Investasi 1(2): 190204.

Sugiyono. 2011. Metode Peneitian Kuantitatif, Kualitatif, dan $R$ dan $D$. Alfabeta. Bandung.

Winantyadi, N. dan I. Waluyo. 2014. Pengaruh Pengalaman, Keahlian, Situasi Audit, dan Etika terhadap Skeptisisme Profesional Auditor. Jurnal Nominal 3(1): 14-34.

Zahmatkesh, S. dan J. Rezazaadeh. 2017. The effect of auditor features on audit quality. Tékhne 15(2): 79-87.

Zarefar, A., Andreas, dan A. Zarefar. 2016. The Influence of Ethics, Experience and Competency toward the Quality of Auditing with Professional Auditor Scepticism as a Moderating Variable. Procedia - Social and Behavioral Sciences, 219: 828-832 